\title{
Reconstruction of Composit Oromandibular Defects
}

\author{
Altuğ ALTINKAYA', Şükrü YAZAR¹, Burak ERTAŞ², Nazım KORKUT², ÖMER FARUK ÜNAL ${ }^{3}$ \\ ${ }^{1}$ Department of Plastic and Reconstructive Surgery, Acibadem University School of Medicine, İstanbul, Turkey \\ ${ }^{2}$ Department of Otorhinolaryngology, Acıbadem University School of Medicine, İstanbul, Turkey \\ ${ }^{3}$ Department of Otorhinolaryngology, Koç University School of Medicine, İstanbul, Turkey
}

\section{ABSTRACT}

Objective: Mandibular defects are generally observed as composite defects which soft tissue defects are accompanied to bone defects. This situation may cause difficulties in choosing the surgical method during the reconstruction period. The purpose of this paper is to convey our clinical approach and results on composite mandibular defects.

Methods: Eleven patients, presenting to our clinic between 2011 and 2015, were operated in a single session with the team of otorhinolaryngology, because of oromandibular cancer. Ten of the patients were male and one was woman. The age range was between 7 and 54 ages (Average age 35.5).

Results: While mandibular resection was performed on all patients, skin resection was performed on six patients, mucosa resection was applied on eight patients; and floor of mouth resections on four patients. The occurring composite defects were reconstructed with free fibular flap or free anterolateral thigh flap. In postoperative period total flap loss was observed in one patient, an infection got developed in the flap donor area of one patient. In the long term, distant metastasis was observed in two patients and local relapse in one patient.

Conclusion: In the repair of composite mandibular defects, fibula free flap can be considered as the first option with regard to its bone length, suitability for osteotomy and low donor area morbidity. However, in these cases, it is necessary to consider the patient's age, health condition, location and type of defect in the determination of the suitable reconstruction method.

Keywords: Mandibula, oromandibular defect, reconstruction

\section{Introduction}

The mandible has a particular importance between the head and neck bones. It is a part of the temporomandibular joint and it forms a base for the masseter muscles to hold on. It plays an active role in the functions of chewing, speaking, swallowing, and breathing by providing the tongue to move easily in the oral cavity. It also provides lower-face projection and thus completes the aesthetic integrity of the face. For these functions to continue properly, it is essential to protect the mandibular integrity. The impairment of the mandibular integrity results in malocclusion, restriction in the mouth opening and movements, and projection loss in the lower face. Mandibular defects can develop secondary to oncological surgery, trauma, and osteoradionecrosis or it can be congenital. Defect can be bordered only with bone tissue or mucosa and/or skin loss can be observed with bone tissue. The purpose of the reconstruction of mandibular defects is to return the patients to their previous state functionally and esthetically. In this study, our long-term results in cases with composite mandibular defects and algorithmic approach to mandibular defects will be discussed.

\section{Methods}

Eleven patients who were admitted to our hospital between 2011 and 2015 with complaints of swelling in the face and non-healing wound in the mouth and in whom tumoral pathology was considered in the result of preoperative examination were operated in a single session by the otorhinolaryngology team. Data used in this study were obtained by the

Cite this article as: Altınkaya A, Yazar Ş, Ertaş B, Korkut N, Ünal ÖF. Reconstruction of Composit Oromandibular Defects. Bezmialem Science 2017; 5: $155-61$.

$\begin{array}{lll}\text { Address for Correspondence: Burak Ertaş; Kulak Burun Boğaz Anabilim Dalı, Acıbadem Üniversitesi Tıp Faküktesi, } & \text { Received } & : 29.08 .2016 \\ \text { İstanbul, Türkiye E-mail: drbertas@yahoo.com } & \text { Accepted } & : 13.10 .2016 \\ \text { oCopyright } 2017 \text { by Bezmialem Vakif University - Available online at www.bezmialemscience.org } & \end{array}$


retrospective screening of patients' medical records. Written informed consent was received from all patients included in the study. While complaints in nine patients had just begun, one patient who underwent partial mandibulectomy and excision in the mouth floor for tumor visited our hospital due to recurrent lesion and one patient who previously underwent excision in the left zygoma and in the lower lip for squamous cell carcinoma sought a consultation for newly emerging ulcerated mass in the mouth floor. Ten patients were male and one was female, and the age range was between 7 and 54 years (mean, 35.5 years). The lesion was located on the left side in seven patients, on the right side in three, and in the midline in one patient. Pathologic examination revealed squamous cell carcinoma in seven patients, ameloblastoma in three, and desmoplastic fibroma in one. After tumoral resection, according to the Jewel classification system, the $\mathrm{HC}$ segment+mucosa+floor of the mouth was observed in one patient; $\mathrm{H}$ segment+skin in one; $\mathrm{H}$ segment+mucosa together with the skin in patient; $\mathrm{H}$ segment+mucosa and skin and oral cavity defect in one; L segment+mucosa+floor of the mouth in two; L segment+mucosa in two; $\mathrm{L}$ segment+skin in two; and nearly the whole mandible, except for the condyles, and accompanying mucosa and skin loss in one. The length of the bone defect after mandibular resection ranged from 4 to $13 \mathrm{~cm}$ (mean, $8.6 \mathrm{~cm}$ ). The length of skin defects accompanying the bone defect ranged from 4 to $18 \mathrm{~cm}$ (mean, 11.1 $\mathrm{cm}$ ), and the defect width ranged from $3 \mathrm{~cm}$ to $13 \mathrm{~cm}$ (mean, $5.5 \mathrm{~cm}$ ). After mandibular resection, the bone defect length ranged from 4 to $13 \mathrm{~cm}$ (mean, $8.6 \mathrm{~cm}$ ). The defects observed on the mouth floor ranged from $4 \mathrm{~cm}$ to $12 \mathrm{~cm}$ (mean, 7.1 $\mathrm{cm}$ ) in length and from $3 \mathrm{~cm}$ to $6 \mathrm{~cm}$ (mean, $3.5 \mathrm{~cm}$ ) in width. Intraoral mucosal defects ranged from $4 \mathrm{~cm}$ to $8 \mathrm{~cm}$ in length (mean, $6 \mathrm{~cm}$ ) and from $3 \mathrm{~cm}$ to $4 \mathrm{~cm}$ (mean, $3.5 \mathrm{~cm}$ ) in width (Table 1).

\section{Results}

In all patients, the tumoral lesion was radically excised by the otolaryngology team. Unilateral neck dissection was performed in seven patients and bilateral neck dissection in two. While the bone defect was repaired with free fibula in eight patients, the reconstruction plaque was used to repair the bone defect in three. Condyle prosthesis was used to repair the defect in four patients with condylar defects. All free fibula flaps that were prepared were adapted to the defect area with the reconstruction plaque. The skin island of the free fibula flap was used to repair the skin defect in three of six patients with skin defects, and anterolateral thigh flap was used in the other three patients. The skin island of free fibula flap was used for repairing the defect in five patients with mucosal defects accompanying the bone defect, and free anterolateral thigh flap was used in three patients. The skin island of the free fibula flap was used to close the mouth floor defect in two of four patients with bone and mouth floor defects, and free anterolateral thigh flap was used in the other two patients. For anastomosis, a suitable branch of the superior thyroid artery and the internal jugular vein were used in ten patients and the facial artery and concomitant vein were used in one. Primary closure was performed in the flap donor site of the three patients with free anterolateral thigh flap. The free fibula flap donor site was closed with split thickness skin graft in five patients, and primary closure was performed in three. At the donor site of a patient in whom free fibula flap was applied, an infection developed during the early postoperative period, and after an appropriate treatment and VAC dressing, the donor site was closed with split thickness skin graft. One of the patients who underwent free anterolateral thigh flap reconstruction had total flap loss during the postoperative period, and then the defect of this patient was closed with pedicle pectoralis major flap. After the wound healing was completed in the patients, none of the controls had difficulty in speaking and swallowing and these functions were sufficient. In the sixth month of postoperative follow-up, squamous cell carcinoma recurred in the mouth floor of a patient. After the area of recurrence was re-excised, it was primarily closed with local tissues. In the $24^{\text {th }}$ month of the postoperative follow-up, one patient died due to pleural metastasis. In the $33^{\text {rd }}$ month of the postoperative follow-up, one patient died due to lung metastasis.

\section{Table 1. Demographic data of patients}

\begin{tabular}{|c|c|c|c|c|c|c|c|}
\hline Patient & Gender & Age & Etiology & Location of defect & Defect type & Recipient vein & Complication \\
\hline 1 & $M$ & 16 & Ameloblastome & LEFT & $\mathrm{HC}+\mathrm{m}+\mathrm{t}$ & STA and IJV & \\
\hline 2 & $M$ & 48 & SCC & LEFT & $\mathrm{H}+\mathrm{C}$ & STA and IJV & Donor area - VAC - Graft \\
\hline 3 & $M$ & 33 & SCC & RIGHT & $L+m+t$ & FA and FV & \\
\hline 4 & $M$ & 30 & Ameloblastome & LEFT & $L+m$ & STA and IJV & \\
\hline 6 & $M$ & 29 & Ameloblastome & LEFT & $L+m$ & STA and IJV & \\
\hline 7 & $M$ & 54 & SCC & RIGHT & $L+m+t$ & STA and IJV & \\
\hline 8 & $M$ & 24 & SCC & RIGHT & $L+C$ & STA and IJV & \\
\hline 9 & $M$ & 77 & SCC & LEFT & $H+c+m+t$ & STA and IJV & Flap necrosis - Pec. Mj \\
\hline 10 & $\mathrm{~F}$ & 46 & SCC & BILATERAL & $\mathrm{LCL}+\mathrm{c}+\mathrm{m}$ & STA and IJV & \\
\hline
\end{tabular}




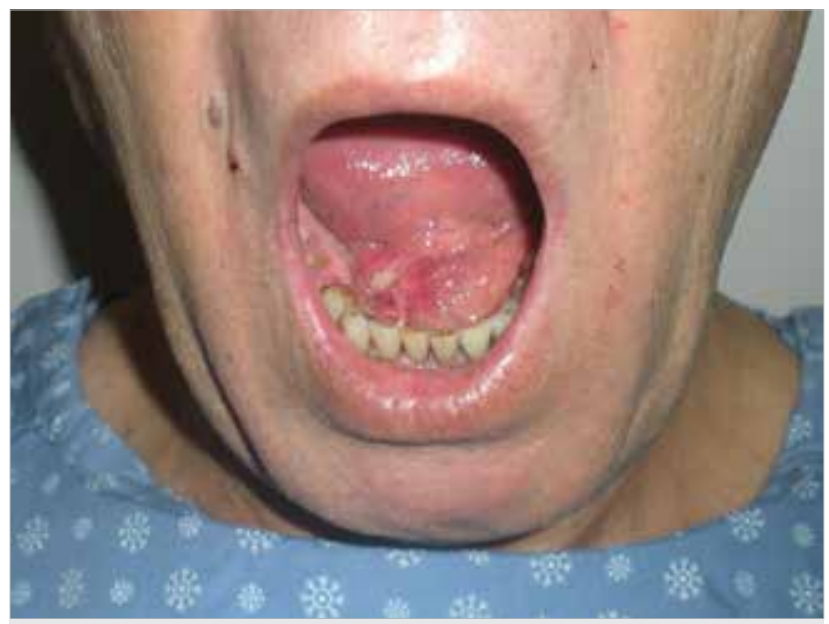

Figure 1. a. Preoperative image of the ulcero-vegetant mass in the mouth

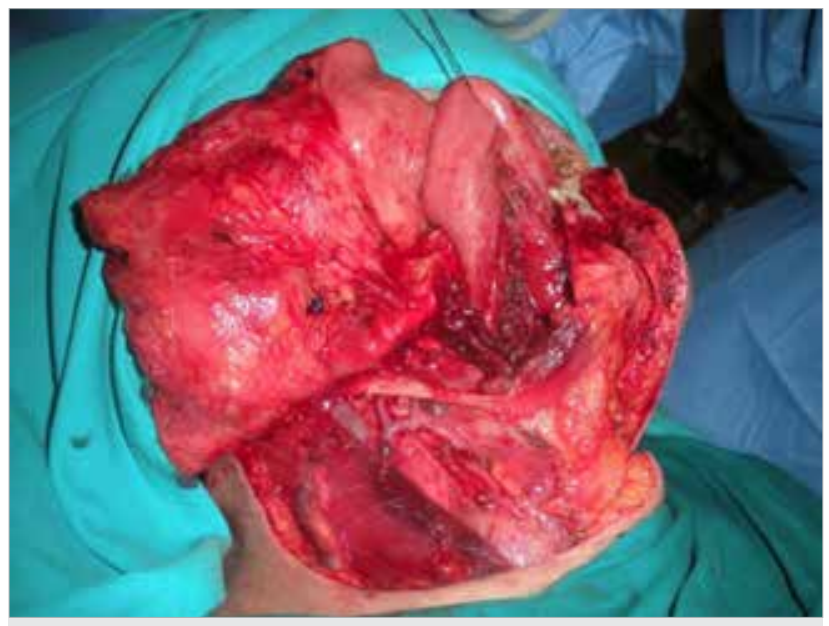

Figure 1. b. Defect occurring after radical resection

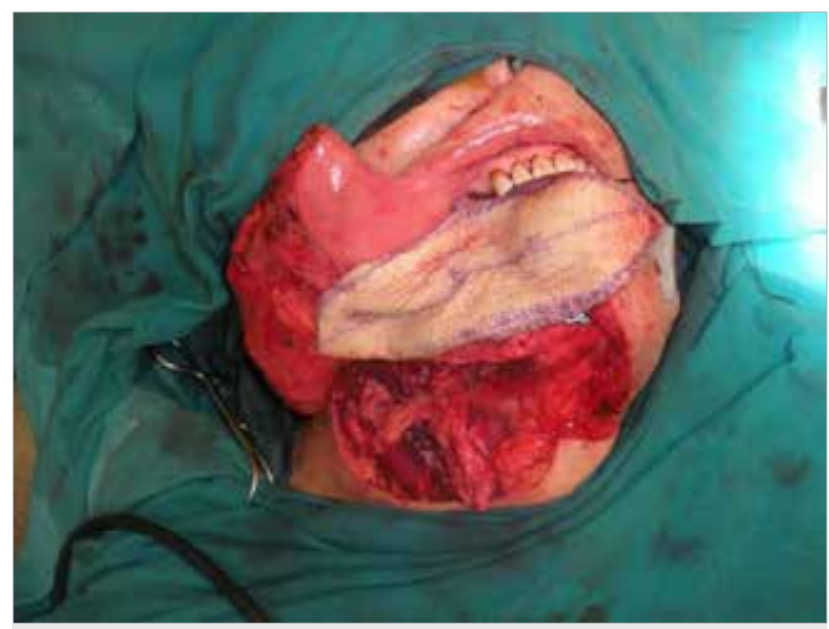

Figure 1. c. Adaptation of the flap to the defect site

\section{Case 1}

A 54-year-old patient was admitted to our clinic due to a nonhealing wound and a bad smelling flow on the mouth floor. An ulcero-vegetant mass adhered to the lingual mucosa of the alve-

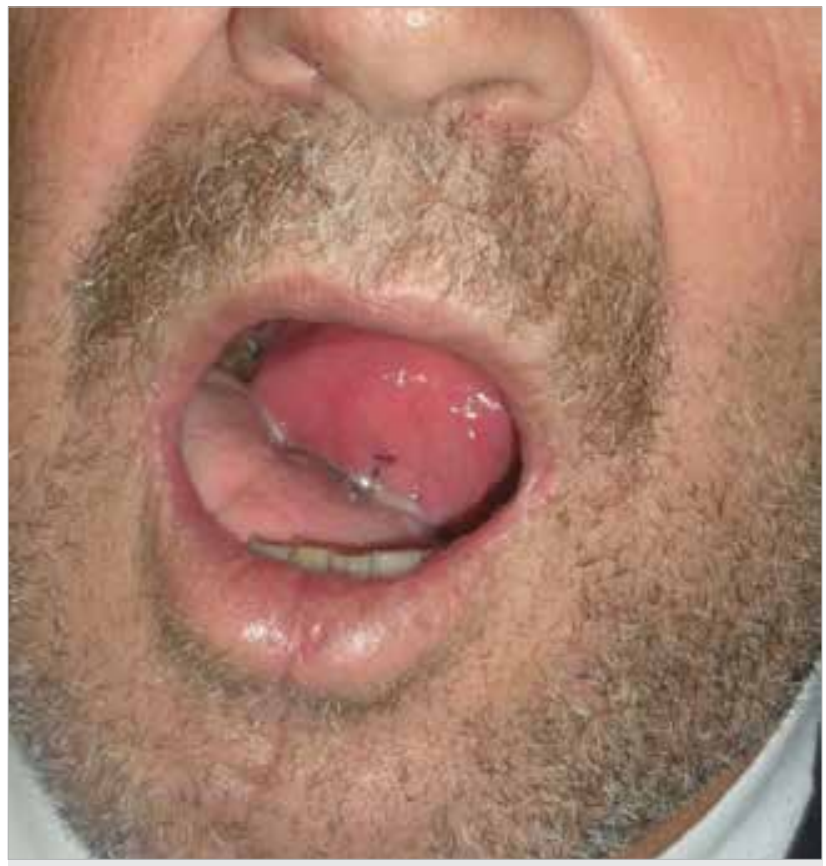

Figure 1. d. Appearance in the postoperative third month

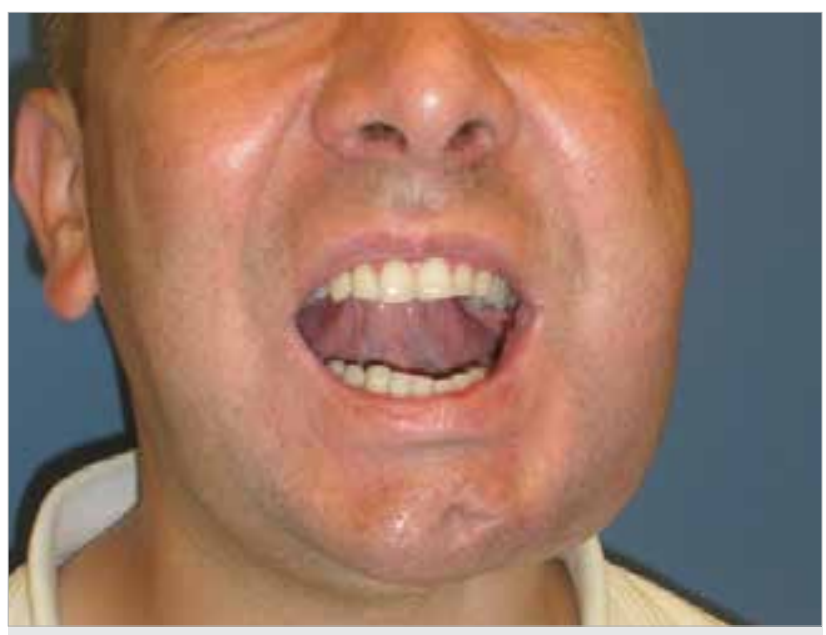

Figure 2. a. Preoperative appearance of the patient

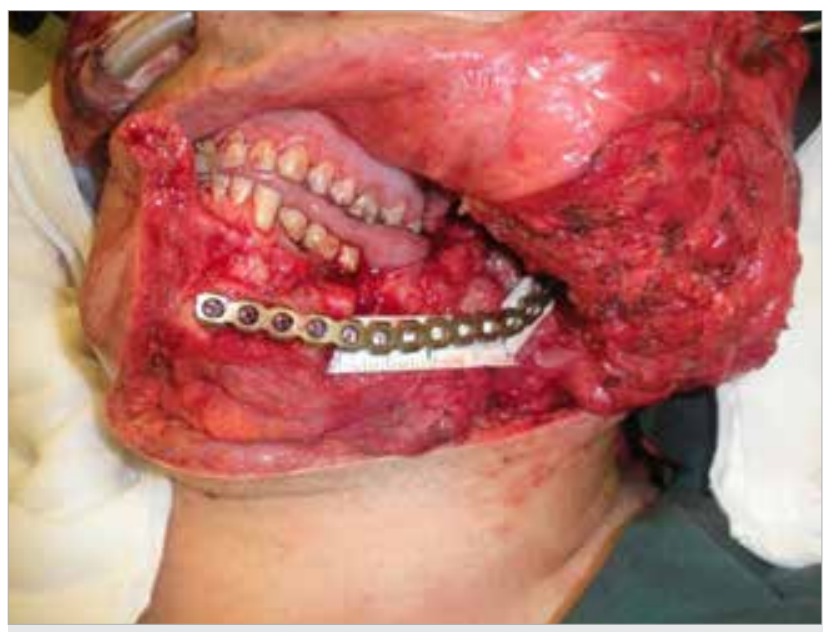

Figure 2. b. Defect occurring after radical resection 


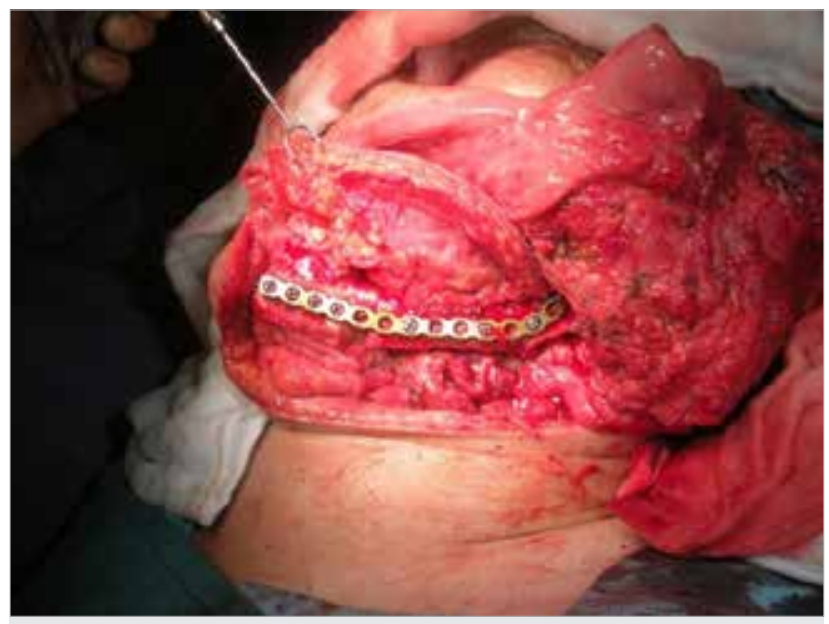

Figure 2. c. Adaptation of the flap to the defect site

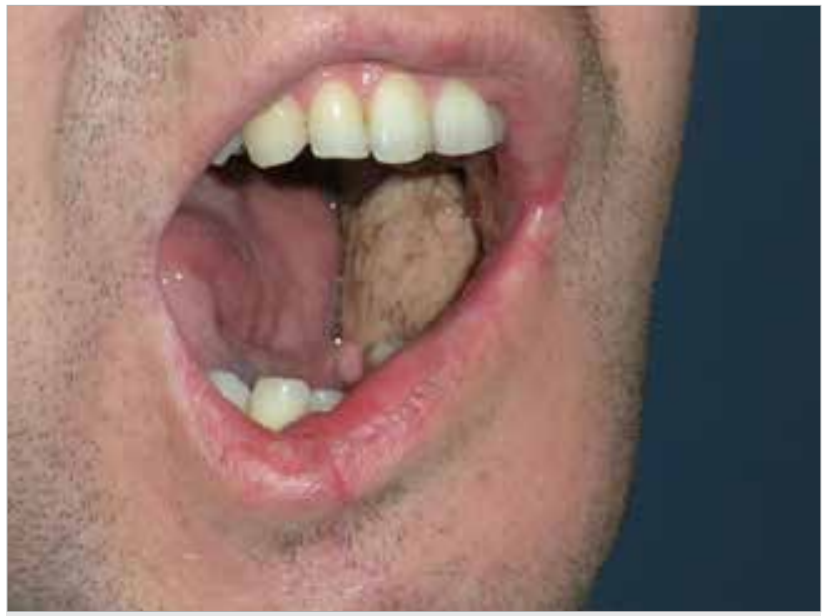

Figure 2. d. Appearance in the postoperative third month

olar arcus on the right front side of the mouth, and a submandibular palpable lymph node was detected (Figure 1a). Biopsy performed on the mass taken from the mouth floor revealed squamous cell cancer. The mandibular corpus was surgically resected by the otolaryngology team, and modified radical dissection was performed on the right side and selective neck dissection was performed on the left side (Figure 1b). The resulting $12-\mathrm{cm}$ bone and $8 \times 3-\mathrm{cm}$ mucosa defects were reconstructed with free osteocutaneous fibula flap (Figure 1c). No complications were observed during the postoperative period. A smooth recovery was achieved, and no recurrence was observed during the 27-month postoperative follow-up (Figure 1d).

\section{Case 2}

A 30-year-old male patient consulted our clinic due to swelling on the left half of the face. A mass showing expansive growth was detected in the left mandibular angulus (Figure 2a). After preoperative radiological examination, the patient was taken up for surgery, and the otorhinolaryngology team performed a partial mandibulectomy, which included the mucosal tissue (Figure $2 \mathrm{~b}$ ). The resulting $8-\mathrm{cm}$ bone and $4 \times$

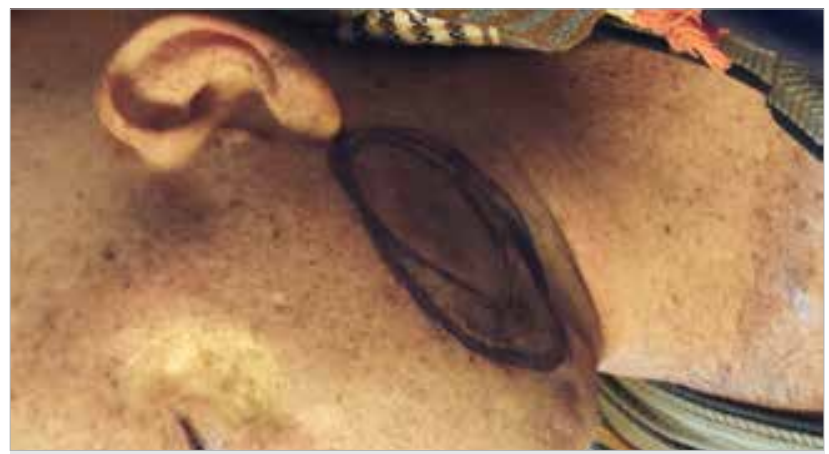

Figure 3. a. Preoperative appearance of the patient

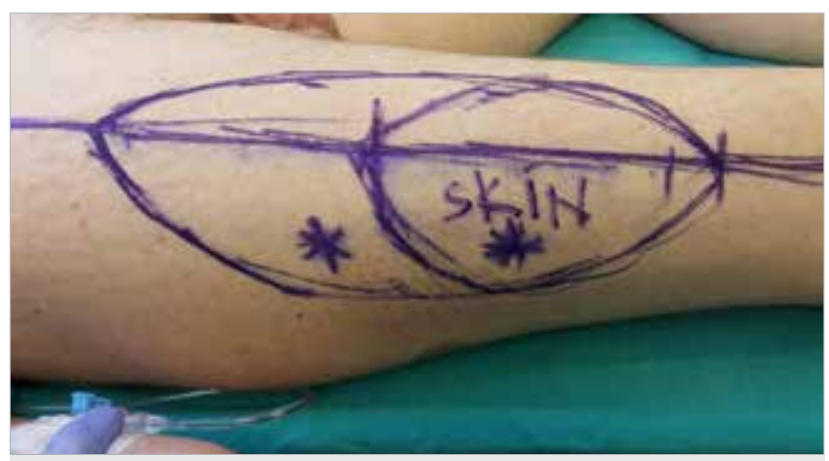

Figure 3. b. Design of free anterolateral thigh flap

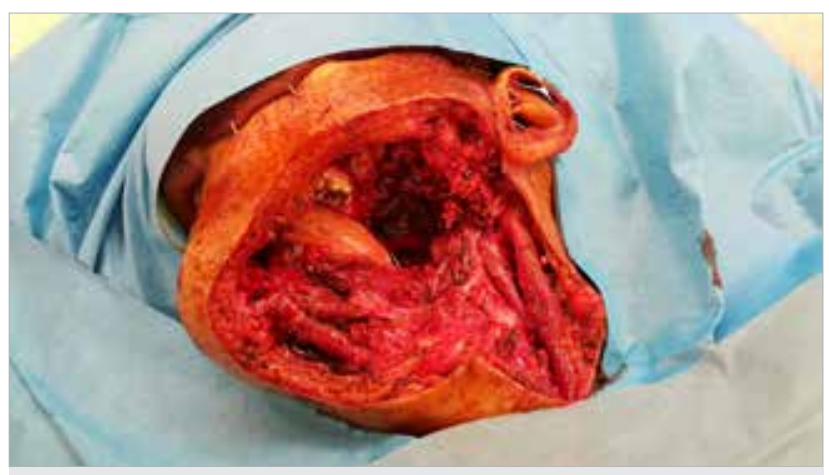

Figure 3. c. Defect occurring after radical resection

free osteocutaneous fibula flap (Figure 2c). A smooth recovery was achieved during the postoperative period. No recurrence was observed during the 13-month postoperative follow-up (Figure 2d).

\section{Case 3}

A 27-year-old male patient who was operated on due to squamous cell carcinoma in the left malar region and lower lip 14 years ago consulted our polyclinic with a bad smelling ulcerovegetant mass on the left half of the face (Figure 3a). The patient was scheduled for surgery. Free anterolateral thigh flap planning and execution were performed on the left thigh to close the defects that would occur (Figure 3b). During the surgery, the otolaryngology team excised the mass infiltrating the mandibular corpus, including the mucosa and the skin (Figure 3c). Left selective neck dissection was performed on 


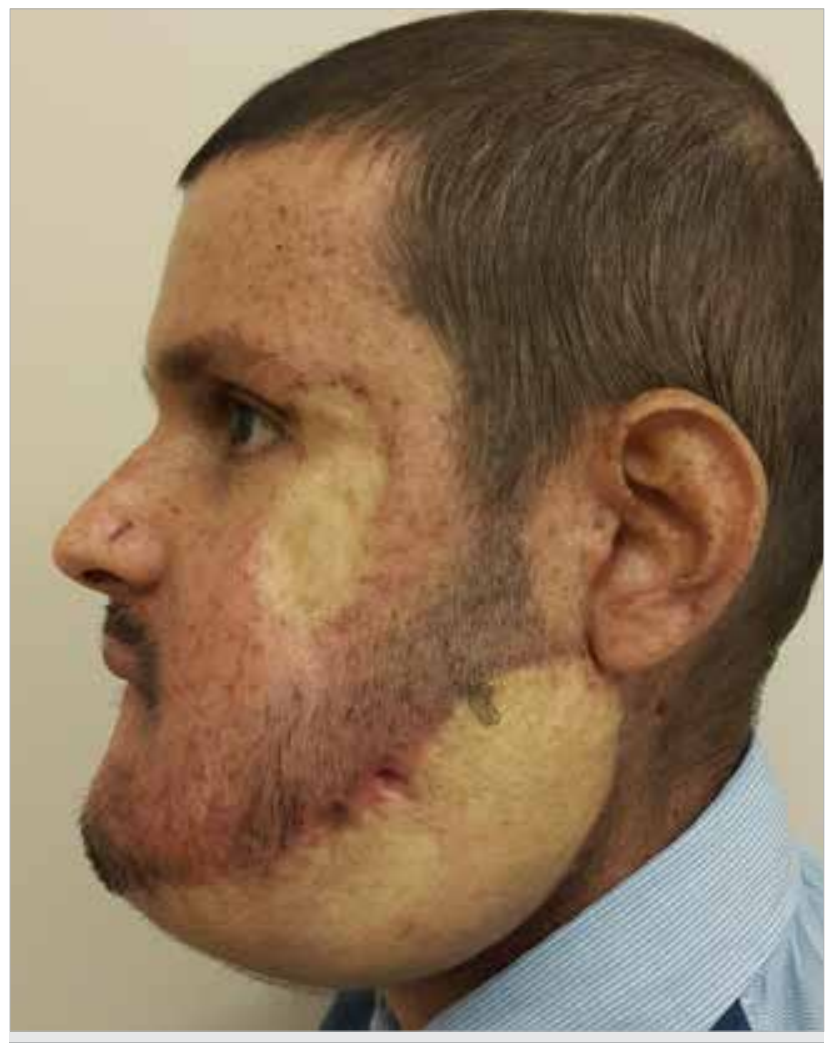

Figure 3. d. Defect occurring after radical resection

the patient. While the resulting $13-\mathrm{cm}$ hemimandibular bone defect was reconstructed with reconstruction plaque and condylar prosthesis, the $8 \times 6-\mathrm{cm}$ defect on the skin and the $4 \times$ $4-\mathrm{cm}$ mucosal defect were covered with the prepared free anterolateral thigh flap. While a smooth recovery was observed during the postoperative period (Figure 3d), lesions consistent with recurrence were detected in the mouth floor and in the retromolar trigone region in the third month. These lesions were excised and the resulting defects were primarily closed using local tissues. After the second surgery, no recurrence was observed during the 16-month follow-up.

\section{Discussion}

In mandibular bone defects, there are two types of reconstruction methods, namely avascular and vascular. The localization of bone defect, the extent of defect in the adjacent tissues, and the length of the defect site are taken into consideration while determining the method to be applied.

Nonvascular bone grafts can be used in mandibular defects with a length of $<5 \mathrm{~cm}$. To use this method, soft tissue vascularity should be intact $(1,2)$. The complication rate is higher in mandibular reconstruction with nonvascular bone graft and bone healing is worse compared with those in patients in whom vascular restoration is performed $(3,4)$. In our clinic, mandibular repair with bone graft is performed on patients in whom the defect is limited to the bone tissue; in whom the defect length is $<3 \mathrm{~cm}$; who have not received radiotherapy, undergone trauma, etc., which may destroy the soft tissue blood supply; and who will not receive radiotherapy treatment during the postoperative period.

Another nonvascular repair method is the repair with reconstruction plaques and screws, in which complication rates have been reported to vary between $7 \%$ and $69 \%(5,6)$. Because the burden on the lateral side of the mandible is less in repair with reconstruction plaque and screw, this method is more suitable for lateral segment defects. Because complications such as plaque exposition, fractures, and orocutaneous fistulas can occur in the long term, elderly patients who are unable to endure long surgical procedures and have more comorbidities and only have a bone tissue defect are suitable for repair with this method.

The development and widespread use of microvascular surgery have reduced the use of nonvascular techniques, and mandibular reconstruction with vascularized techniques has become more popular. Fibula, iliac wing, scapula, and radial forearm flaps are frequently used in vascularized mandibular repairs.

The scapular flap can be elevated together with the bone and the soft tissue to a large extent. It can also be designed and prepared in the form of a chimeric flap containing multiple skin islands (7). Therefore, it is a suitable choice for patients with large soft tissue defects or for those with full-thickness defects. The bone length it provides is approximately $14 \mathrm{~cm}$ (8). It can be prepared in two segments and provided with blood through separate arteries with a single osteotomy. However, it is not suitable for central mandibular defects that require bone shaping with osteotomy. Because of the need for repositioning during surgery, it is also not suitable for two-team work (9). Although the reduced joint range of motion and difficulty in lifting heavy objects were the most important donor site morbidities (10), it was reported in the study conducted by Coleman (11) that pain, movement restriction, and loss of strength were moderately graded by most patients and that these did not lead to any limitation in everyday life.

The iliac flap should be considered as the first choice in the repair of hemimandibular defects because it is anatomically similar to the hemimandible (12). With the iliac flap, bone tissue can be included in the flap in large sizes and at a height equal to the mandible. The fact that bone tissue height corresponds to the natural mandibular height facilitates the application of osteointegrated implants, provides support for the lower lip, and provides a better oral competence $(9,13)$. Osteotomy cannot be performed because of the lack of segmental blood supply (8). The flap has a short pedicle and a stationary skin island, which make it difficult to repair complex defects with mucosa and skin involvement. High donor site morbidity observed, such as abdominal hernia, and other morbidities, such as walking difficulty and postoperative pain, also limit the use of this flap $(14,15)$. 
Radial forearm osteocutaneous flap allows the repair of uneven three-dimensional soft tissue defects accompanying the mandibular bone defect. It can be elevated with a large, soft, and thin skin island that can be shaped. Long vascular pedicle and facility for two-team work are the other advantages. It is suitable rather for the reconstruction of intraoral defects. Because the radial bone that can be elevated is thin and monocortical, it is not suitable for shaping with osteotomy and for dental implants (16). Fractures in the radial bones were reported in patients in whom this flap was used; to prevent this, it is recommended that the flap should be elevated to not $>30 \%$ of the radial bone diameter, the radial bone should be fixed with the plaque, or one of the bone graft applications should be performed (16-20).

Fibula flap provides bicortical bone tissue of up to $30 \mathrm{~cm}$ and can be used alone for total mandibular reconstruction (21). It is suitable for shaping with multiple osteotomies because of its segmental blood supply. In patients in whom anastomosis is required on the contralateral side, the length of pedicle is usually sufficient and vein graft applications are not needed. Soleus or hallucis longus muscle may be included in the flap $(22,23)$. It can be prepared as a chimeric flap and used for the repair of small diameter, full-layer composite mandibular defects (22). It has a low donor site morbidity $(24,25)$. Because the bone height is less than the natural mandibular height, for the implantation of the osteointegrated implant, the flap should be insetted close to the upper border of the mandible, should be insetted as double barrel, or its height should be extended with distraction osteogenesis (26-28). Although the height is insufficient in dental implant applications, it is the first choice in patients with edentulous mandibles because the mandibular height is equal to the flap height (29). There are two major disadvantages related to the skin island; its insufficient ability to freely move and its being thin. Therefore, it is not an option for the repair of large soft tissue defects with dead space. In our series, eight patients had mandibular bone defects with an average length of $8.6 \mathrm{~cm}$ and accompanying soft tissue defects in various sizes. The defect length was over $3 \mathrm{~cm}$ in all patients. Most of the eight patients were in the middle or young age group (eight patients; mean age, 30.1 years). Considering the advantages and low donor site morbidity, free fibula flaps were the first choice in these patients.

Three patients in our series had a very large soft tissue defect accompanying the bone defect. The oldest of these patients was aged 77 years. This patient had a large tumoral lesion involving the skin, mouth floor, and mucosa in addition to the left half of the mandible. Another patient previously underwent a mandibular resection and was admitted to our clinic due to recurrence even after two chemotherapy cycles. The third patient previously underwent excision due to squamous cell carcinoma in the left zygoma and in the lower lip. This patient visited us due to a newly emerging squamous cell carcinoma in the mandible. Because of little chance of cure and a high possibility of recurrence, the bone defect of these three patients was repaired with a reconstruction plaque and the large soft tissue defect was repaired with free anterolateral thigh flap, and the plaque was closed with a thick and reliable soft tissue cover. Thus, it was aimed to increase the quality of life of the patients, to decrease the surgery time, and to minimize complications related to the prolonged surgery time. Apart from our approach, the use of different free flaps has been reported for bone and soft tissue repair in these cases.

\section{Conclusion}

As a result, the use of vascularized repair methods is often required for mandibular reconstruction. The vascularized osteocutaneous fibula flap should be considered as the first choice in terms of the fact that it is easy to be shaped, provides bone tissue of up to $30 \mathrm{~cm}$, and has a very low donor site morbidity than the other free flap options.

Ethics Committee Approval: Ethics committee approval was received for this study from the Ethics Committee of Acıbadem University (2016-11/1).

Informed Consent: Written informed consent was obtained from the patient who participated in this study.

Peer-review: Externally peer-reviewed.

Author Contributions: Concept - Ş.Y.; Design - A.A.; Supervision - B.E.; Resources - A.A.; Materials - N.K.; Data Collection and/or Processing - A.A.; Analysis and/or Interpretation - Ö.F.Ü.; Literature Search - B.E.; Writing Manuscript - A.A.; Critical Review - Ş.Y.

Conflict of Interest: No conflict of interest was declared by the authors.

Financial Disclosure: The authors declared that this study has received no financial support.

\section{References}

1. Hutchison I. Reconstructive surgery: Bone and cartilage harvesting. In: Langdon JD, Patel MF, eds. Operative Maxillofacial Surgery. London: Chapman \& Hall Medical; 1998: 93110

2. Wilk RM. Bony reconstruction of the jaws. In : Miloro M, ed. Peterson's Principles of Oral and Maxillofacial Surgery. 2nd ed. Hamilton, Ontario: Decker; 2004: 783-801

3. van Gemert JT, van Es RJ, Van Cann EM, Koole R. Nonvascularized bone grafts for segmental reconstruction of the mandible--a reappraisal. J Oral Maxillofac Surg. 2009 Jul;67(7):144652. [CrossRef]

4. Foster RD, Anthony JP, Sharma A, Pogrel MA. Vascularized bone flaps versus nonvascularized bone grafts for mandibular reconstruction: an outcome analysis of primary bony union and endosseous implant success. Head Neck. 1999 Jan;21(1):6671. [CrossRef]

5. Wei FC, Celik N, Yang WG, Chen IH, Chang YM, Chen HC. Complications after reconstruction by plate and soft-tissue free flap in composite mandibular defects and secondary salvage reconstruction with osteocutaneous flap. Plast Reconstr Surg. 2003 Jul;112(1):37-42. [CrossRef]

6. Cordeiro PG, Hidalgo DA. Soft tissue coverage of mandibular reconstruction plates. Head Neck. 1994 Mar-Apr;16(2):112-5. [CrossRef] 
7. Gibber MJ, Clain JB, Jacobson AS, Buchbinder D, Scherl S, Zevallos JP et al. Subscapular system of flaps: An 8-year experience with 105 patients.Head Neck. 2015 Aug;37(8):1200-6. Epub 2014 Jul 10. [CrossRef]

8. Goh BT, Lee S, Tideman H, Stoelinga PJ. Mandibular reconstruction in adults: a review.

9. Int J Oral Maxillofac Surg. 2008 Jul;37(7):597-605. Epub 2008 May 1. Review.

10. Bak M, Jacobson AS, Buchbinder D, Urken ML. Contemporary reconstruction of the mandible. Oral Oncol. 2010 Feb;46(2):71-6. Epub 2009 Dec 29. [CrossRef]

11. Sullivan MJ, Carroll WR, Baker SR. The cutaneous scapular free flap in head and neck reconstruction. Arch Otolaryngol Head Neck Surg. 1990 May;116(5):600-3. [CrossRef]

12. Coleman SC, Burkey BB, Day TA, Resser JR, Netterville JL, Dauer E, et al. Increasing use of the scapula osteocutaneous free flap. Laryngoscope. 2000 Sep;110(9):1419-24. [CrossRef]

13. Rana M, Warraich R, Kokemüller H, Lemound J, Essig H, Tavassol F, et al. Reconstruction of mandibular defects - clinical retrospective research over a 10-year period .

14. Head Neck Oncol. 2011 Apr 28;3:23. [CrossRef]

15. Moscoso JF, Keller J, Genden E, Weinberg H, Biller HF, Buchbinder D, et al. Vascularized bone flaps in oromandibular reconstruction. A comparative anatomic study of bone stock from various donor sites to assess suitability for enosseous dental implants. Arch Otolaryngol Head Neck Surg. 1994 Jan;120(1):36-43 [CrossRef]

16. Urken ML. Composite free flaps in oromandibular reconstruction. Review of the literature. Arch Otolaryngol Head Neck Surg. 1991 Jul;117(7):724-32. Review. [CrossRef]

17. Brown JS. Deep circumflex iliac artery free flap with internal oblique muscle as a new method of immediate reconstruction of maxillectomy defect. Head Neck. 1996 Sep-Oct;18(5):412-21. [CrossRef]

18. Mounsey RA, Boyd JB. Mandibular reconstruction with osseointegrated implants into the free vascularized radius. Plast Reconstr Surg. 1994 Sep;94(3):457-64. [CrossRef]

19. 17 )Weinzweig N, Jones NF, Shestak KC, Moon HK, Davies BW. Oromandibular reconstruction using a keel-shaped modification of the radial forearm osteocutaneous flap. Ann Plast Surg 1994;33:359-369; discussion 369-370 63.
20. Thoma A, Allen M, Tadeson BH, Archibald S, Jackson S, Young JE. The fate of the osteotomized free radial forearm osteocutaneous flap in mandible reconstruction. J Reconstr Microsurg 1995;11:215-21964.

21. Thoma A, Khadaroo R, Grigenas O, Archibald S, Jackson S, Young JE, et al. Oromandibular reconstruction with the radial-forearm osteocutaneous flap: experience with 60 consecutive cases. Plast Reconstr Surg 1999;104:368-378; discussion 379-380 [CrossRef]

22. Kim JH, Rosenthal EL, Ellis T, Wax MK. Radial forearm osteocutaneous free flap in maxillofacial and oromandibular reconstructions. Laryngoscope 2005;115:1697-1701. [CrossRef]

23. Wei F, Seah C, Tsai Y, Liu S. Fibula osetoseptocutaneous flap for reconstruction of composite mandibular defects. Plast Reconstr Surg 1994;93:294-304 [CrossRef]

24. Hidalgo DA, Rekow A. A review of 60 consecutive fibula free flap mandible reconstructions. Plast Reconstr Surg 1995;96:585-596; discussion 597-602 35.

25. Wong CH, Ong YS, Chew KY, Tan BK, Song C. The fibula osteoseptocutaneous flap incorporating the hemisoleus muscle for complex head and neck defects: anatomical study and clinical applications. Plast Reconstr Surg 2009;124: 1956-196 [CrossRef]

26. Bodde EW, de Visser E, Duysens JE, Hartman EH. Donorsite morbidity after free vascularized autogenous fibular transfer: subjective and quantitative analyses. Plast Reconstr Surg 2003;111:2237-2242 [CrossRef]

27. Chou SW, Liao HT, Yazar S, Lin CH, Lin YC, Wei FC. Assessment of fibula osteoseptocutaneous flap donor-site morbidity using balance and gait test. J Orthop Res. 2009 Apr;27(4):555-60. [CrossRef]

28. Horiuchi K, Hattori A, Inada I, Kamibayashi T, Sugimura M, Yajima H, et al. Mandibular reconstruction using the double barrel fibular graft. Microsurgery 1995;16:450-454 [CrossRef]

29. Iizuka T, Hallermann W, Seto I, Smolka W, Smolka K, Bosshardt DD. Bi-directional distraction osteogenesis of the alveolar bone using an extraosseous device. Clin Oral Implants Res 2005;16:700-707 47.

30. Schleier P, Hyckel P, Fried W, Beinemann J, Wurdinger J, Hinz $M$, et al. Vertical distraction of fibula transplant in a case of mandibular defect caused by shotgun injury. Int J Oral Maxillofac Surg 2006;35:861-864 [CrossRef]

31. Kademani D, Mardini S, Moran SL. Reconstruction of head and neck defects: a systematic approach to treatment. Semin Plast Surg. 2008 Aug;22(3):141-55. [CrossRef] 